ISSN: 1641-4713; e-ISSN: 2081-1160

DOI: https://doi.org/10.36551/2081-1160.2020.26.25-38

\title{
The Valley of Dawn in the Brazilian Religious Field
}

\section{El Valle del Amanecer en el campo religioso brasileño}

\author{
Amurabi Oliveira \\ Department of Sociology and Political Science \\ Federal University of Santa Catarina (UFSC), Brazil \\ ORCID iD: https://orcid.org/0000-0002-7856-1196 \\ E-mail: amurabi1986@gmail.com
}

Recepción: 16.12.2019

Aprobación: 4.05.2020

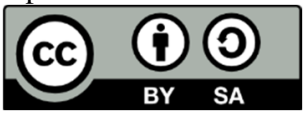

\begin{abstract}
The Valley of Dawn is a religious movement that emerged in Brasilia in the second half of the twentieth century, founded by Neiva Chaves Zelaya (1925-1985), known as Tia Neiva (Aunt Neiva). In this movement there is an intense religious syncretism, which is denied by the believers, as well as a strong presence of elements from the Afro-Brazilian religions, such as the caboclos and pretos velhos. The purpose of this article is to understand what this movement reveals from the dynamics of the Brazilian religious field, indicating some tensions that exist, mainly from its relationship with other religions.
\end{abstract}

Keywords: Valley of Dawn, new religions, Brazilian religious field, New Age, Umbanda.

Resumen: El Valle del Amanecer es un movimiento religioso que surgió en Brasilia en la segunda mitad del siglo XX, fundado por Neiva Chaves Zelaya (1925-1985), conocida como Tia Neiva (Tía Neiva). En este movimiento hay un intenso sincretismo religioso, que es negado por los creyentes, así como una fuerte presencia de elementos de las religiones afrobrasileñas, como los caboclos y los pretos velhos. El propósito de este artículo es comprender lo que este movimiento revela de la dinámica del campo religioso brasileño, indicando algunas tensiones que existen, principalmente por su relación con otras religiones.

Palabras clave: Valle del Amanecer, nuevas religiones, campo religioso brasileño, Nueva era, Umbanda. 


\section{INTRODUCTION}

For researchers and the curious entering a Vale do Amanhecer (VDA) Valley of Dawn temple for the first time, the experience is always intense and remarkable. The profusion of colors and signs, the brilliance of ninfas ${ }^{1}$ clothing, the multiple references from Dr. Fritz to Tutankhamen produce a sense of dejà $v u$. Everything seems new but at the same time, seems to cause a strange sense of familiarity.

The sense of familiarity also stems from the fact that the VDA continually oscillates between the different experiences of Brazilian popular religiosity, especially Umbanda and Brazilian Spiritism (i.e. Espiritismo Kardecista), besides the New Age. In terms of both imagery and the composition of the rituals that make up their practices, in the Valley we find multiple religious and cultural references. Mediums incorporate pretos velhos and caboclos, and when incorporated, they give "passes," which is a recurring practice in Brazilian Spiritism, where the imposition of hands would imply the transposition of bioenergy from one person to another. As Pierini explains (2014, p. 293):

In their spiritual practice, mediums in a semi-conscious trance state embody a wide range of spiritual beings, including pretos velhos (spirits of African old slaves), caboclos (spirits of Amerindians), médicos de cura (spirits of doctors), gypsies, princesses and spirits of the waters, among others. These are referred to as spirit 'mentors' for they are held to bring from the higher spirit worlds guidance, protection, and healing to human beings. The spiritual treatment is referred to as 'disobsessive healing' (cura desobsessiva), involving the release of causal spiritual agents understood as afflicting (obsessing) the patient. Differently from spirit mentors, these spirit categories - namely, suffering (sofredores), obsessing (obsessores) spirits, or creditors from past lives (cobradores) - are described as discarnate beings trapped in-between the physical and spiritual worlds after death, feeding themselves through humans' energy, causing a wide range of disturbances in their material life or physical health.

To the researchers, it is evident how syncretic the Valley of Dawn is. Still, this interpretation is rejected by the believers, who perceive in this movement a completely original formulation, even though they also see certain continuities with other religions, especially Brazilian Spiritism. For the believers, the denial that the Valley is a religion is recurrent, claiming that it is, in fact, a doctrine. Believers deny that VDA is a religion, and they also deny the existence of any syncretism in this movement.

\footnotetext{
${ }^{1}$ Ninfa (Nymph) is how women who are initiated into the Valley of Dawn movement are recurrently named.
} 
Although there is some heterogeneity in the composition of the believers of the Valley, I highlight the fact that its symbolic universe is forged from experiences common to Brazilian popular strata. Neiva Chaves Zelaya (1925-1985), the founder of this movement, was a woman who moved from the Brazilian Northeast to Central Brazil during the construction of Brasília (the new National Capital) she was part of the group that became known as candangos ${ }^{2}$. By this, I mean that the symbolic and religious elaboration that Neiva Zelaya created tends to come close to her class habitus, her biographical experiences, as well as the class habitus of a significant portion of the participants in this doctrine.

Considering these aspects, which mark the uniqueness and complexity of this esoteric mystical universe, I intend to reflect on what the VDA reveals to us about the Brazilian religious field. From a single case (the VDA), we can explore elements for a broader understanding of the religious dynamics in Brazil, its symbolic hierarchies, and its changes.

\section{VALLEY OF DAWN: A BRIEF ITINERARY}

There is no way to disentangle the history of the VDA from the life trajectory of Neiva Chavez Zelaya, best known among supporters as Tia Neiva (Aunt Neiva). According to biographical accounts, until Neiva Zelaya was 32 years old she had a normal life, when she then claimed to have the most diverse visions. From that moment, she began a pilgrimage through traditional medicine, Catholicism, Brazilian Spiritist centers, and Umbanda in search of answers. Her spiritual pilgrimage leads us to a recurring trajectory in the Brazilian religious field, marked by conversions and transits ${ }^{3}$.

At the age of 33 she had a first contact with an entity that called himself Pai Seta Branca (White Arrow Father), a fact that is discursively highlighted by the believers due to the current idea that 33 was the age is believed to have been Jesus Christ's age believed. Through numerous contacts with this entity, Tia Neiva claims to have learned that in other incarnations, she would have been a Greek pythoness in Delphi, the Egyptian Nefertiti and Cleopatra, plus a Gypsy known as Natascha.

\footnotetext{
${ }^{2}$ Candango is a word commonly used pejoratively to refer to workers who immigrated to the future capital of Brazil (Brasilia) for its construction.

3 This narrative is widely reproduced by adepts in this movement, who claim to be real events, but everything is based on Tia Neiva's biography (Neiva, 1992).
} 
The image of Pai Seta Branca ${ }^{4}$ is sometimes confused with that of Jesus himself, occupying a more prominent place among the entities that make up the cosmology of the Valley, despite being doctrinally viewed as hierarchically inferior to Jesus (Mello, 1999). Cavalcante (2005, p. 168) remarks, concerning not only to Pai Seta Branca but also to the other "indigenous" entities that appear in the Pantheon of the Valley:

The Valley of Dawn speaks of Andean, Mesoamerican, Brazilian, and North American indigenous peoples, all of whom are exposed to a strong mythical aura and apparently arrived there through systems such as travel agency brochures and travel souvenirs; as well as the Umbanda religion; New Age religiosity, and also from Western movies and series, which are aired on film and television (Author translation).

I understand that the composition of the religious, mystical universe of the Valley is only possible within the process that Ortiz (2006) calls the globalization of culture, in which different signs are deterritorialized and passed on, to be reworked in a new context. I argue that the Indians from the Valley of Dawn belong to the universe proper to this movement, considering that there was a complex process of resignification and reinvention of these symbols.

Still, regarding the religious pilgrimage experienced by Tia Neiva, supporters report that she met Mãe Nenen with whom she founded in Serra do Ouro, near the city of Alexânia, between the cities of Brasilia and Anápolis, the União Espiritualista Cristã Seta Branca (Christian Spiritualist Union Seta Branca), better known among supporters by the acronym UESB. Although this experience did not last over time, it served as the initial nucleus for the organization of the Valley, as well as reinforcing the importance of Brazilian Spiritism for the process of systematization of VDA doctrine.

While in UESB (1959-1964) Tia Neiva claims to have been trained by a monk named Humahã, who was alleged to have lived at the Lhasa monastery in Tibet. According to supporters, for 5 years Neiva would have moved spiritually every day to receive the training. By the end of it, she would have been given the name "Koatay 108", which would refer to a supposedly luminous crown of 108 diamonds that would have been placed over her head, as well as to the knowledge of 108 mantras.

\footnotetext{
${ }^{4}$ According to the VDA mythology Pai Seta Branca originally came from another planet, passing through several reincarnations in which he was an Inca jaguar, St. Francis of Assisi, and, in his last life on earth, a Tupinambá Indian.
} 
There were later disagreements between Tia Neiva and Mãe Nenen that culminated in the separation of the two, although this passage is not elucidated in detail in Tia Neiva's biographies. According to Cavalcante (2000), this fact is explained by the believers as a fulfillment of "karmic debt." Tia Neiva and Mãe Nenén would have been linked in past lives, and the time spent together would have served to pay this "debt."

In 1964 Tia Neiva moved to the outskirts of Taguatinga with a small group of mediums. In this city her missionary work was registered under the name Ordens Sociais da Ordem Espiritualista Cristã (Social Orders of the Christian Spiritualist Order). It was just a change of name, as there was already a record in the mold of a religious community with social works, which remained under the name of UESB. For believers in the spiritual plane, the community would have the name from the Corrente Indiana do Espaço (Indian Space Chain).

Later this group was joined by a person who was decisive in the process of constitution of the Valley, Mario Sassi (1921-1995), Tia Neiva's last husband who became the main systematizer of the doctrine of the Valley of Dawn (Galinkin, 2008).

As far as the temple itself is concerned, there were legal problems that led to the loss of the ground on which Tia Neiva's group was housed, and a further change of location was required. The group moves to the outskirts of Planaltina, Satellite City of Brasilia, where finally, the community installation takes place. It is in this place that the doctrine gets the name of Valley of Dawn, referring to the sighted dawn of that place.

Tia Neiva died in 1985, apparently due to tuberculosis. To the adepts, such a disease had a spiritual explanation, would stem from a "karmic debt," and would have occurred after her training with the Tibetan monk. Before her death, Neiva had prepared her succession, with four trinos ${ }^{5}$ commanding the Valley from this moment. These trinos are Mario Sassi (Trino Tumuchy), his son, Gilberto Chaves Zelaya (Trino Ajarã), supporters Nestor Sabatovicz (Trino Arakém) and Michel Hanna (Trino Sumanã). Tia Neiva's two daughters had a few minor roles in doctrine structure.

It is noteworthy that in the year of Tia Neiva's death there were only four VDA temples outside Brasilia (Galinkin, 2008). Today there are already more than 700, and twelve temples abroad, located in the United States, Portugal,

\footnotetext{
${ }^{5}$ This term refers to the hierarchical position in the movement.
} 
Bolivia, England, Trinidad and Tobago, and French Guyana ${ }^{6}$. These temples have administrative autonomy, but do not have doctrinal autonomy. There is also a significant difference in terms of temple size, physically, and the number of believers.

\section{The Valley of Dawn as Popular NeW AgE}

As stated earlier, there is a strong connection between the VDA and Brazilian Spiritism, especially in terms of doctrinal organization. In this sense, the Valley incorporates Brazilian Spiritism but expands it, producing dialogues with other cultural and religious matrixes, especially Umbanda, which historically also dialogues with Brazilian Spiritism (Prandi, 2012). However, I would like to highlight a dialogue that I understand as fundamental to the analysis of the VDA as a religious movement: its approach to the New Age.

First, I would like to start with a critique of this approach represented by Calou (2018) that interprets the VDA as a religious movement based on Brazilian Spiritism, diverging from the New Age holistic perspective. In fact, the adepts reinforce this discusses, but as we examine their practices, we can find many other elements that dialogue directly with the New Age cultural matrix.

To understand this argument we must recognize that the New Age movement is a profoundly diffuse movement devoid of rigid doctrinal foundations (Amaral, 2000; De La Torre, 2014; Hanegraaff, 2018; Magnani, 2000; Possamai, 2019; Steil et al., 2018; Sutcliffe \& Gilhus, 2014). We would hardly find in empirical reality a religion that would be an "ideal type" of New Age religion. To claim that the VDA is part of the broader composition of the New Age means to recognize; therefore, certain principles are shared and resignified, highlighting the energy category, which is central to the New Age (Oliveira, 2016; Tavares, 2012; Tavares \& Caroso, 2018).

Another characteristic present in the VDA that produces a strong approximation with the New Age is the centrality of the therapeutic character of its practices (Pierini, 2018). As Tavares (2012) well demonstrates, therapeutic practices in the New Age universe constitute a multiple and diffuse set that can both approach and distance from popular religions in Brazil.

\footnotetext{
${ }^{6}$ The addresses of all VDA temples are available at https://www.valedoamanhecer.com.br/. Last consultation on June 9, 2019. For a better analysis of the presence in the Valley of Dawn in other countries see the work of Vásquez and Alves (2013).
} 
Moreover, even the most traditional religions are in a continuous process of transformation, and in many cases are also impacted by the New Age (Guerriero, 2009; Oliveira, 2014, 2020; Oliveira \& Boin, 2018), incorporating certain elements, albeit in a resignified way. Therefore, in this article, I interpret the Valley of Dawn as part of the diffuse New Age universe in Brazil, but I understand that this movement is a more original synthesis that I call the Popular New Age. I understand this category as a reinvention of New Age, incorporating elements from the popular religions that were ignored earlier in this cultural matrix, reinterpreting its rituals, symbols and doctrine (Oliveira, 2009).

I interpret that the VDA produces an original articulation within the New Age movement, by articulating references to largely imaginary Egyptian, Mayan, Greek, Hindu, and so on, with elements present in Brazilian popular religions, represented mainly by the Caboclos and Pretos Velhos, which are central in Umbanda cult. This articulation permeates the different social markers that are placed in the founders of the VDA, as well as in their believers since it makes visible symbolic and cultural elements strongly present in the reality of these subjects.

\section{WHAT DOES THE VALLEY OF DAWN REVEAL TO US ABOUT THE BRAZILIAN RELIGIOUS FIELD?}

Mário Sassi (1979), as already indicated, played a significant role in the constitution of the Valley as we know it today, being the main systematizer of the doctrine. In the book $O$ que é o Vale do Amanhecer? ("What is the Valley of Dawn?"), he ponders two fundamental aspects: a) the VDA would not be a religion but a doctrine; b) that the believers refuse the existence of any form of syncretism, indicating that the Valley would be something original because it was the result of a revelation. I believe that to understand such points; it is necessary to return to the figure of the prophet, in the terms that Bourdieu (2004) interprets Weber's sociology of religion (Weber, 1999), indicating that this agent is involved in offering new "goods of salvation" (Rey, 2004). The prophet can bring new "goods of salvation" to the religious field giving a new interpretation to old "goods of salvation", presenting them with new terms, as a rupture with the institutionalized religion.

The distinction between religion and doctrine among believers was usually made by comparison with Brazilian Spiritism, indicating that Brazilian Spiritism would be a religion while VDA would be a doctrine. This distinction is not so clear but seems to be connected to the fact that other religions are more insti- 
tutionalized, according to the adepts. On an empirical level, we can affirm that this distinction is more a kind of self-representation, that helps to build a symbolic distinction between the VDA and other religious movements. Although this division has always seemed to me to be quite tenuous in my fieldwork, I understand that the denial of the religion label is vital for the building of the believers' sense of their religious belonging.

Tia Neiva, playing the role of prophet, deftly fulfilled this role by creating a whole complex universe that fills the eyes of those who first come to a VDA temple. In this sense, the statement that the Valley would not be the result of syncretism is of great importance for the statement of the "goods of salvation" offered, presented as something completely original.

We can see some continuity between the Valley and Umbanda. However, I understand that this movement is closer to a "Umbandist esotericism", considering that despite incorporating elements originally belonging to Afro-Brazilian religions, the identity Afro is denied (Oliveira, 2014). This can be understood more broadly as a reflection of the "whitening" of Afro-Brazilian religions, as already observed by other authors (Motta, 1977; Ortiz, 1999).

The focus of the Valley's action is what they call "disobsessive healing," which implies a process of re-interpreting the afflictions of the "patients"7. According to supporters, this is charity work that is developed by the movement. The idea of charity in this movement - as part of the spiritual evolution - reaffirms its theological link with Brazilian Spiritism. In these terms, "disobsessive healing" is the main form of charity offered by the mediums, and also the more relevant "good of salvation" of the Valley.

The most common ritual in the various temples of the VDA in Brazil is what is called the trono (throne), in which there is a direct communication with the old caboclos and pretos velhos, incorporated in the mediums that are called aparás, and the relationship with the "patient" through non-incorporating mediums, called doutrinadores. Although there is a distinction between the two kinds of mediums, they are not watertight categories, and there are cases of mediums who have transited between these two possibilities. According to Pierini (2014, p. 294-295):

In comparison with other Brazilian mediumistic religions, because of the emphasis the Vale puts upon spirit release (addressed as 'disobsession'), the practice of apara' and doutrinador may be positioned more closely to the Brazilian Spiritist practice (i.e. Espiritismo Kardecista), rather than to Afro-Brazilian trance states.

\footnotetext{
${ }^{7}$ This is the denomination that those who belong to the VDA give to those who seek the spiritual services of the Valley.
} 
I partially disagree with this interpretation of Pierini, since I realize that the doutrinador and the apará types constitute poles that dialogue in different ways with the Brazilian mediumistic religions, the first being closer to Brazilian Spiritism and the second to Afro-American religions (Oliveira, 2015). It can be seen, therefore, that the Valley brings with it another constitutive element of the Brazilian religious field: the possibility of personalized communication with entities. The resolution of people's everyday problems would be, in this interpretative process, situated not only at the most objective and material level but also at the level of the sensible, most easily grasped through communication with "another spiritual plane."

The consultation to which I referred in the trono ritual constitutes a first stage of the "spiritual treatment," for it is here that these entities have indicated the other rituals by which the "patient" must submit. It may involve a series of ritualistic activities in the Valley temple itself, especially larger temples.

Despite the central presence of caboclos and pretos velhos, believers tend to deny any direct connection between the VDA and Afro-Brazilian religions, arguing that these entities in the Valley do not use tobacco or alcohol, nor would they interfere with people's free will. It shows a fundamental tension in the Brazilian religious field, in which the elements of Afro-Brazilian religions are, normally, at the same time recognized for their effectiveness, but delegitimized in terms of social prestige (Maggie, 1992).

According to the adepts, the pretos velhos or caboclo present in the Valley were not slaves or Indians in other incarnations. This is just their appearance as a spiritual mentor. Among those most revered entities, with which some believers and "patients" develop a relationship of greater complexity, we can mention some figures such as Pai Zé Pedro de Enoque, Mãe Tildes, Pai Joaquim das Praias, Pai João de Guinea, Vó Mariana das Cachoeiras, Caboclo Tupinambá, Ubirajara, Cabocla Jurema, Cabocla Iracema, and so on, whose biographies would often de known by believers.

The recursive use of elements from Afro-Brazilian religions is also felt in the performance produced at the time of incorporation. They snap their fingers, clap their hands against their chests and wriggle their faces, representing their connection with the "higher astral." Although there are more common ways of incorporating old caboclos and pretos velhos, each medium has his way of performing this process. In other terms: 
The process of personalization of the entities, therefore, mixes several elements that are linked, in one way or another, to the biographical recreation that the movement itself performs, since the pretos velhos and caboclos of the Valley command spiritual phalanges, they are spirits of light that they inhabit the higher astral, many of them coming from other planets aboard flying saucers. By presenting themselves as entities known in AfroBrazilian cults, this means that these elements are also present in the incorporation, especially in the linguistic plane. When the already incorporated medium gives his blessings to the patient, he makes references to various entities, such as the Greater East, Mãe Iara, Apollo, Bezerra de Menezes, etc. This is not a simple process, nor a closed one; even though there are elements strongly tied by the doctrine, there is a space of inventiveness, and it is in this open breach that incorporation takes on its most fascinating contours when a new subject who is no longer exclusively an entity or medium is born, it is a third being that originates, the junction, the mixture and the overcoming of these first two (Oliveira, 2013, p. 34, Author translation).

Within the circuit of existing rituals in a large Valley temple, there are a few other rituals that will feature the presence of pretos velhos and caboclos so that communication with these entities is commonplace for those seeking the "goods of salvation" of the Valley. After some time, the believers get more intimacy with the entities, calling them by diminutive names. Eventually, this also reverberates in a kind of proximity to the preto velho or the caboclo of a particular medium, thus recognizing the agency of both the medium and the entity. This becomes even more evident in the context of religious modernity, where it is possible to belong to a creed without believing or to believe without belonging (Hervieu-Léger, 2008).

This experience distances itself from the analytical models that try to explain the New Age phenomenon, placing it in what Amaral (2000) calls "community without essence," precisely from the centrality of the "techniques" and the multiplicity of experiences rather than deepening them. For most believers, and for a significant portion of the "patients" who attend the temples, the relationship with the Valley tends to be more intense and long-lasting, although this does not automatically exclude other religious experiences. In this sense, the Valley also draws our attention to the multiple possibilities of experiencing the "Age of Aquarius" practices.

These questions can be better understood by considering the Weberian model of prophecy. The German sociologist indicates that from the five major world religions we can find two types of prophecy. They are the exemplary and the emissary, the first shows the way to exemplary life, usually to a contemplative and apathetic life; the second addresses its demands to the world in the name of a god (Weber, 2002). 
In the cosmological universe of the VDA, we find a kind of hybrid prophecy since it can be, in a sense, equally framed as exemplary and as an emissary (or missionary). On the one hand, the Valley's prophecy is emissary because it focuses on adopting a model of life to follow, whether it be from Pai Seta Branca on a spiritual plane or Tia Neiva herself on a material plane, and believes that God's emissaries one day will return to earth to rescue sinners. This prophecy, according to Weber, requires practice in and for the world. On the other hand, it would also be exemplary in that the responsibility for everything that happens to be good and bad in one's life is the responsibility of the subject himself. In this way, each individual must assume his debts and these will be expiated through internal improvement and internalization practices.

Weber (2002) also points out that in missionary prophecy, devotees perceive themselves as instruments of a god. In the Valley both attitudes are present, for as vessels of the divine, they consider themselves to be energy carriers; therefore, they must assist others when necessary, either by transmitting energy or in their process of individual improvement. In the Valley, exemplary and ethical behaviors are inseparable, and in this way build a new lifestyle for believers which dialogues with Brazilian Spiritism, Afro-Brazilian religions, Catholicism, and the new age.

\section{FINAL CONSIDERATIONS}

In this article, I sought to review some points that I consider relevant to the understanding of the dynamics of the VDA and the Brazilian religious field itself, thinking how this movement reflects certain issues related to the tensions, disputes, and hierarchies proper to this field.

The VDA takes some elements from the Afro-Brazilian religions, recognizing how relevant the pretos velhos and caboclos are in the Brazilian religious field. But, at the same time this religious movement gives a new interpretation for these elements. To the adepts, pretos velhos and caboclos were not slaves or indigenous people in other incarnations. They were evolved spirits that have the role of spiritual mentors in this moment. This double movement reveals the place of Afro-Brazilian religions in the Brazilian religious field dynamics, religions that at the same time are recognized by its magical powers but are also stigmatized.

The denial of syncretism, as well as the label of religion, is also emblematic of the new religious movements and how they think to offer their "goods of salvation." In a religious movement so syncretic, as the Valley is (from the social 
scientist's point of view), this scenario challenges the social scientists of religion to rethink their ideas of religion and syncretism. How can we still use these categories when the "natives" deny it?

Tia Neiva's biography, on the other hand, shows us the creativity presents in the popular groups and how they can dialogue with a large number of cultural matrices. Not only Catholicism, Umbanda and Brazilian Spiritism are present in this religious formulation, but also elements from New Age. The feeling that a non adept has in a VDA temple Tia Neiva has produced a unique world, with such different elements that everything seems new and familiar at the same time.

Last but not least, the Valley makes us rethink the literature produced about the New Age movement, especially about this movement in Brazil. Although there is a very heterogeneous audience that seeks the spiritual services offered by the VDA, for a significant part of the adepts and patients the spiritual experience in the VDA is not something ephemeral. It could be very meaningful spiritual, and sometimes it results in a religious conversion, the beginning of a new life, as some adepts used to say.

\section{REFERENCES}

Amaral, L. (2000). Carnaval da alma: Comunidade, essência e sincretismo na Nova Era. Vozes.

Bourdieu, P. (2004). A economia das trocas simbólicas. Perspectiva.

Calou, A. L. F. (2018). De sodomitas a príncipes maias: uma análise queer das teopolíticas do Vale do Amanhecer [Master's thesis, Federal University of Paraíba].

Cavalcante, C. L. C. (2000). Xamanismo no Vale do Amanhecer: O caso Tia Neiva. Annablume.

Cavalcante, C. L. C. (2005). Dialogias no Vale do Amanhecer: Os Signos de um Imaginário Religioso Antropofágico. [Doctoral dissertation, Pontifical Catholic University of São Paulo]. TEDE PUC-SP.

De La Torre, R. (2014). Los newagers: el efecto colibrí. Artífices de menús especializados, tejedores de circuitos en la red, y polinizadores de culturas híbridas. Religião \& Sociedade, 34(2), 36-64. https://doi.org/10.1590/S1984-04382014000200003

Galinkin, A. L. (2008). A Cura no Vale do Amanhecer. Technopolitik.

Guerriero, S. (2009). Novas configurações das religiões tradicionais: ressignificação e influência do universo Nova Era. Tomo, (14), 35-53. https://doi.org/10.21669/tomo.v0i14.497

Hanegraaff, W. J. (2018). Esotericism in the Mirror of Secular Thought. Brill.

Hervieu-Léger, D. (2008). O Peregrino e o Convertido: A Religião em Movimento. Vozes.

Maggie, Y. (1992). Medo de Feitiço: Relações entre a Magia e o Poder no Brasil. Arquivo Nacional.

Magnani J. G. C. (2000). O Brasil da Nova Era. Zahar. 
Mello, G. B. R. (1999). Millénarismes brésiliens : Contribution à l'étude de l'imaginaire contemporain [Doctoral dissertation, Université Pierre Mendes France].

Motta, R. (1977). As variedades do espiritismo popular na área do Recife: ensaio de classificação. Boletim da Cidade do Recife, (2), 97-114.

Neiva, T. (1992). Autobiografia Missionária. Vale do Amanhecer.

Oliveira, A. (2009). Nova Era à Brasileira: A New Age Popular do Vale do Amanhecer. Interações: Cultura e Comunidade, 4(5), 31-48.

Oliveira, A. (2013). Os caboclos e pretos-velhos do Vale do Amanhecer. Ciências da Religião História e Sociedade, 11(2): 14-38.

Oliveira, A. (2014). A Nova Era com Axé: umbanda esotérica e esoterismo umbandista no Brasil. Revista Pós Ciências Sociais, 11(21), 167-184.

Oliveira, A. (2015). Os Corpos no Vale do Amanhecer: entre o kardecismo e a umbanda. Debates do NER, 2(28), 231-251. https://doi.org/10.22456/1982-8136.61275

Oliveira, A. (2016). "É Tudo Energia" - A Nova Era e a Umbanda em diálogo. REVER, 16(2), 92107. https://doi.org/10.21724/rever.v16i2.29387

Oliveira, A. (2020). Umbanda as Syncretistic Shamanism in Barcelona. International Journal of Latin American Religions, 4(1), 123-136. https://doi.org/10.1007/s41603-020-00097-0

Oliveira, A. \& Boin, F. (2018). New Age Umbanda: Axé and Energy in the Context of the Religious Transformations. Studia Religiologica, 51(4), 219-231. https://doi.org/10.4467/20844077SR.18.016.10100

Ortiz, R. (1999). A Morte Branca do Feiticeiro Negro: Umbanda e Sociedade Brasileira. Brasiliense.

Ortiz, R. (2006). Mundialização e Cultura. Brasiliense.

Pierini, E. (2014). Becoming a Spirit Medium: Initiatory Learning and the Self in the Vale do Amanhecer. Ethnos, 81(2), 290-314. https://doi.org/10.1080/00141844.2014.929598

Pierini, E. (2018). Healing and Therapeutic Trajectories Among the Spirit Mediums of the Brazilian Vale do Amanhecer. International Journal of Latin American Religions, 2(2), 272-289. https://doi.org/10.1007/s41603-018-0054-5

Possamai, A. (2019). In Search of New Age Spiritualities. Routledge. https://doi.org/10.4324/9781315252490

Prandi, J. R. (2012). Os Mortos e os Vivos: uma introdução ao espiritismo. Três Estrelas.

Rey, T. (2004). Marketing the goods of salvation: Bourdieu on religion. Religion, 34(4), 331-343.

Sassi, M. (1979). O que é o Vale do Amanhecer? Guavira.

Steil, C. A., De La Torre, R., \& Toniol, R. (Eds.) (2018). Entre trópicos: Diálogos de estudios Nueva Era entre México y Brasil. Casa Chata; Centro de Investigaciones y Estudios Superiores en Antropología Social.

Sutcliffe, S. J., \& Gilhus, I. S. (Eds). (2013). New Age Spirituality: rethinking religion. Routledge. https://doi.org/10.4324/9781315729541

Tavares, F. (2012). Alquimistas da cura: a rede terapêutica alternativa em contextos urbanos. Edufba. 
Tavares, F., \& Caroso, C. (2018). Is It Still Possible to Talk About New Age Therapeutic Religiosities? International Journal of Latin American Religions, 2(2), 207-220. https://doi.org/10.1007/s41603-018-0053-6

Vásquez, M. A., \& Alves, J. C. S. (2013). The Valley of Dawn in Atlanta, Georgia: Negotiating Incorporation and Gender Identity in the Diaspora. In: C. Rocha \& M. A. Vásques (Eds.). The Diaspora of Brazilian Religions (313-337). Brill. https://doi.org/10.1163/9789004246034_014

Weber, M. (1999). Economia e Sociedade. Vol 1. Editora UnB.

Weber, M. (2002). Ensaios de sociologia. LTC. 